\title{
BIBLIJNY KONTEKST HYMNU MAGNIFICAT
}

Fragment pierwszego rozdziału Ewangelii Łukasza (Łk 1,46-55) należy do gatunku literackiego, który można by nazwać hymnem dziękczynno-wielbiącym. W trzeciej osobie liczby pojedynczej odnosi się on do Boga oraz jest wypowiedzią Maryi skierowaną do Elżbiety, w pisującą się w narracyjny kontekst sceny Nawiedzenia (Łk 1,39-46).

Stylistyka hymnu oraz charakterystyka językowa noszą szczególne znamiona semickie. Magnificat nie tylko zawiera aluzje i odniesienia do tekstów starotestamentowych, ale już na poziomie lingwistycznym sprawia wrażenie, jakby powstał w języku hebrajskim lub aramejskim. W artykule zwrócę uwagę na trzy poziomy, które tworzą starotestamentowe tło hymnu Maryi.

Pierwszym jest poziom językowy. Celem ilustracji przedstawię próbę retrowersji z języka greckiego na hebrajski, opierając się na wydaniach tekstu Nowego Testamentu w języku hebrajskim ${ }^{1}$ oraz własnej intuicji lingwistycznej. Następnym poziomem będą analogie do wybranych zwrotów lub wersetów starotestamentowych. Trzecim zaś - odniesienia do ważnych pojęć i idei obecnych na kartach Starego Testamentu.

Literalnie pierwszy werset poematu można z greckiego przełożyć: Moje życie (dusza) czyni wielkim (wywyższa) Jahwe i raduje się duch mój Bogiem, moim Wybawca (Łk 1,46-47), po hebrajsku zaś mógłby brzmieć: Teromem nafszi et Adonaj, wattagel ruchi bElohe jisz’i. Wyraźnie widzimy tu konstrukcję paraleliczną, w której „życiu”

1 Ha-Berit ha-Chadasha, tłum. Franz Delitzsch, London 1960; Torah Nebi'im Ketubim weha-Berit ha-chadaszah, The Bible Society in Israel, Jerusalem 1991. 
(gr.psychē; hebr. nefesz) odpowiada „duch” (gr. pneuma; hebr. ruach), wyrażeniu „czyni wielki” (gr. megalynei; hebr. teromem) - czasownik „raduje się” (gr. égalliasen; hebr. wattagel lub wetagel), imieniu Bożemu (JHWH) zaś, które kryje się pod zastępującym go (ze względu na świętość i aby nie użyć Go nadaremno) słowem Pan (gr. Kyrios; hebr. Adonaj) - rozwinięte sformułowanie Bogiem, moim Wybawca (gr. tō theō tō sōtēri mou; hebr. bElohe jisz'i).

Najbliższą paralelą starotestamentową wydaje się początek modlitwy Anny z 1Sm 2,1-10 (1Sm 2,1: Anna modliła się mówiąc: Raduje się me serce $w$ Panu, moc moja wzrasta $w$ Panu, rozwarly się me usta na wrogów moich, gdyż cieszyć się mogę Twoim wybawieniem). Zresztą cały kontekst narodzin i poświęcenia Samuela można odczytywać intertekstualnie, w odniesieniu do narodzin Jezusa i Jana Chrzciciela. Pod względem gatunku literackiego hymn Anny jest bardzo bliski tekstowi Magnificat, z tą jednak różnicą, że wyrażone w drugiej osobie liczby pojedynczej zakończenie $1 \mathrm{Sm} 2,1$ (raduję się Twoim wybawieniem, hebr. samachti biszu'atecha) nadaje całości hymnu charakter modlitwy. Niemniej jednak paralelna konstrukcja 1Sm 2,1: 'alac libbi bAdonaj (raduje się me serce $w$ Panu) oraz rama qarni bAdonaj (moc moja wzrasta $w$ Panu $^{2}$ ) zostaje dokładnie odzwierciedlona w Łk 1,47, co jasno widać w proponowanej rekonstrukcji hebrajskiej.

Radość, mająca źródło w Bogu jako Wybawcy, jest częstym motywem w literaturze profetycznej Izraela. Można tu przytoczyć słowa Habakuka, wypowiedziane w czasach bezpośrednio poprzedzających najazd Babilończyków. Mimo zapowiedzi upadku i klęski prorok w głębi serca znajduje nadzieję: Ja zaś w JHWH będę się weselić, będę się cieszyć w Bogu mojego wybawienia (Hab 3,18). Podobną nadzieję na odmianę losu Izraela można odnaleźć u Proto-Izajasza. W kontekście klęski, jaka dotknie ciemięzców, prorok obwieszcza: Pomnoża poniżeni $w$ JHWH radość a ubodzy ziemi w świętym Izraela będa się cieszyć (Iz 29,19). W szczególności jednak Tryto-Izajasz, prorok odrodzonego Izraela, zanosi dziękczynienie za odnowioną świętość

${ }^{2}$ Literalnie: róg mój wzrasta w Panu. 
Jeruzalem: Radościa będę się radowat w JHWH moja dusza [życie] będzie cieszyć się w Bogu (Iz 61,10).

Drugi wers poematu w literalnym przekładzie brzmi: $G d y \dot{z}$ spojrzat na uniżenie swojej niewolnicy, oto zatem, od teraz będą uważać mnie za szczęśliwa wszystkie pokolenia (Łk 1,48), a w hebrajskiej retrowersji: Ki ra'o ra'a ba'oni 'amato wehinne me'atta kol dorot je'aszszeruni ${ }^{3}$. Pierwsza część wersetu niemalże literalnie podejmuje słowa Anny skierowane do Boga w modlitwie błagalnej, poprzedzającej poczęcie Samuela: JHWH zastępów, jeśli spojrzysz spojrzeniem na uniżenie twojej niewolnicy i będziesz pamiętał o mnie i nie zapomnisz o swojej stużebnicy... i dasz mi potomka męskiego, to oddam go Panu (1Sm 1,11). W mojej retrowersji uznałem nawet za stosowne użyć poetyckiej figury etymologicznej, w której tzw. infinitivus absolutus poprzedza czasow$\mathrm{nik}^{4}$, podobnie jak to ma miejsce w modlitwie Anny ('im ra'o tir'e ba'oni 'amatecha - jeśli spojrzysz spojrzeniem na uniżenie twojej niewolnicy).

Drugą paralelą starotestamentową jest specyficzne użycie czasownika 'aszar w koniugacji piel, który oznacza „uważać, uznawać kogoś za szczęśliwego", czyli obdarzonego Bożym błogosławieństwem. Najbliższym tekstem jest wypowiedź Lei, małżonki Jakuba, wyjaśniająca etymologię imienia Aszer, nadanego jej synowi: I powiedziała Lea w swoim szczęściu: "szczęśliwa będa mnie uważać dziewczęta», i dała mu imię "Aszer» (Rdz 30,13). Słowom Lei 'iszszeruni banot (szczęśliwa będa mnie uważać dziewczęta) odpowiada fraza kol dorot je’aszszeruni (będa uważać mnie za szczęśliwa wszystkie pokolenia) $\mathrm{z}$ naszej hebrajskiej retrowersji kantyku Maryi.

W szerszym kontekście myśli starotestamentowej należy zwrócić uwagę na koncepcję szczęścia połączoną z błogosławieństwem, co sprawia, że zarówno hebrajski czasownik 'aszar, jak i grecki makariōo okazują się trudne do przełożenia, gdyż stawiają tłumacza w sytuacji

\footnotetext{
${ }^{3}$ Mniej przekonująca wydaje się propozycja tłumaczenia Bible Society: hinne «'aszrecha» j'omru meatta uldor dorim.

4 Zarówno Delitzsch, jak i Bible Society używają jedynie formy imperfectum czasownika ra'a w koniugacji piel.
} 
konieczności wyboru pomiędzy ideą szczęścia a błogosławieństwa Ponadto coraz wyraźniej zarysowuje się typologiczny wymiar postaci Maryi w narracji nowotestamentowej. Święte kobiety Starego Testamentu, takie jak Lea i Anna, będące matkami ważnych postaci biblijnych, symbolizujących na płaszczyźnie typologicznej Chrystusa, mogą być postrzegane jako typy Maryi.

Trzeci werset poematu: Gdyż uczynit mi wielkie rzeczy ten, który jest potężny, i święte jest Jego Imię (Łk 1,48), można oddać po hebrajsku: Ki gedolot 'asa li szaddaj weqadosz szemo. Wydaje się on głęboko osadzony w deuteronomistycznej idei świętości Bożego Imienia, która wyraża się poprzez „wielkie dzieła”, jakich dokonuje On w historii Narodu Wybranego. Można by mnożyć aluzje czy to do Wyjścia z Egiptu, czy też do wydarzeń z epoki Sędziów. Lapidarnie idea ta została wyrażona w Ps 111,9: Zesłał odkupienie swojemu ludowi, ustanowił na wieki swoje przymierze, a Jego imię jest święte i budzace trwogę. Podstawowa różnica polega jednak na tym, że w przypadku Magnificat „wielkie dzieła” Boga zostają odniesione do konkretnej osoby, a nie do całego narodu izraelskiego.

Zarówno w tekście Psalmu 111, jak i w proponowanych retrowersjach Magnificat występuje fraza qadosz szemo (święte jest Jego Imię), która wyraźnie odnosi się do chwalebnego imienia JHWH, które ze względu na szacunek Jemu przynależny nie zostało wypowiedziane. Intertekstualnie można by też zestawić te wersety $\mathrm{z}$ wzorcem modlitwy, jaki zaproponował Jezus: Ojcze Nasz, który jesteś w niebiosach, niech będzie święte Twoje imię (Mt 6,9). W hymnie Anny, do którego już wcześniej nawiązywaliśmy, paralelą wydaje się $1 \mathrm{Sm}$ 2,2: Nikt tak święty jak JHWH, prócz Ciebie nie ma nikogo, nikt taką Skała jak Bóg nasz. Tu Imię Boga w postaci tetragramu czytanego Adonaj (Pan) zostało przywołane.

Kolejny werset brzmi: I łaskawość Jego przez pokolenia i pokolenia dla tych, którzy odczuwają przed Nim bojaźń (Łk 1,50), w retrowersji

\footnotetext{
5 Problem ten powraca zwłaszcza przy przekładzie błogosławieństw z Kazania na Górze (Mt 5,1-11). Wiele współczesnych tłumaczeń zamiast „błogosławieni” używa słowa „szczęśliwi”.
} 
hebrajskiej zaś: Wechasdo ledor dorim 'al jere'aw. O ile w poprzednim wersecie dało się odczuć ducha tradycji deuteronomistycznej, o tyle tutaj do głosu dochodzi późniejszy nurt literatury sapiencjalnej, w którym główną cnotą Izraelity była jit’at Adonaj (bojaźń Pańska). To na niej opiera się religijność Syracha, redaktorów Księgi Przysłów i greckiego autora Księgi Mądrości.

Połączenie idei bojaźni Bożej z miłosierną miłością (chesed) zwięźle wyraża Ps 103,17: Łaskawość JHWH od wieku po wiek nad tymi, którzy się go boją. Werset ten jest na tyle bliski tekstowi Magnificat, że izraelskie Bible Society literalnie włączyło go do swojej retrowersji Łk 1,50: Wechesed JHWH méolam wead 'olam 'al jere'aw. Sądzę jednak, że jest to zbyt daleko posunięta manipulacja i mimo oczywistych analogii nie stanowi on cytatu z Psalmu 103.

Aluzja do bojaźni Bożej pojawia się również w Ps 111,10: Bojaźń Pańska początkiem mądrości. Wprawdzie nie ma tu odniesienia do Bożego miłosierdzia, niemniej jednak może zastanawiać sekwencyjne przejście od tematu imienia Bożego do bojaźni Bożej, które obserwujemy zarówno w Łk 1,49-50, jak i w Ps 111,9-10.

Dalej czytamy: Potężne rzeczy uczynit swoim ramieniem, rozproszył wywyższających się zamysłem swoich serc (Łk 1,50), co po hebrajsku brzmiałoby: gewurot 'asa ${ }^{6}$ bizro'o pizzar ge' im bimzimmot lewawam ${ }^{7}$. Pod względem lingwistycznym najbliższą paralelę można odnaleźć w Ps 89,11 (Ramieniem twojej potęgi rozproszyłeś twoich wrogów), z którego zaczerpnąłem podstawowe słownictwo dla retrowersji. Jednak w szerszym kontekście werset przywołuje wydarzenia i refleksję teologiczną związaną z Wyjściem z Egiptu. Bóg wyzwalający, który swoim ramieniem (zeróa) czyni wielkie rzeczy (gedolot), znaki i cuda, przeciwstawiony zostaje zatwardziałemu sercu pysznego Faraona, które odzwierciedla w formie paralelizmu antytetycznego druga część wersetu: rozproszył wywyższających się zamysłem swoich serc. W tym kontekście warto przytoczyć Wj 15,21: A Miriam przyśpiewywała im: «Śpiewajmy pieśń chwały na cześć Pana, bo swa potege

\footnotetext{
6 Według Bible Society: 'asa chajil.

7 Według Bible Society: pizzar 'et 'aszer machszewot ga'awa belibbam.
} 
okazał, gdy konie i jeźdźców ich pogrążył w morzu». Werset wyraża tę samą ideę, co Łk 1,50, a ponadto łączy typologicznie Maryję z siostrą Mojżesza, noszącą to samo imię.

Co do kantyku Anny, jedynie ostatnia część wersetu może nosić znamiona tematycznego odniesienia do $1 \mathrm{Sm}$ 2,3: Nie mówcie więcej słów pełnych pychy, z ust waszych niech nie wychodza słowa wyniosłe, bo Pan jest Bogiem wszechwiedzacym: On waży uczynki. Pycha i wyniosłość człowieka zostaje przeciwstawiona potędze Boga, która w tym przypadku wyraża się w Jego wszechwiedzy i władzy sądzenia.

Następny werset w przekładzie literalnym brzmi: usunął potężnych $z$ tronów, a wywyższył poniżonych (Łk 1,52). Ze względu na różnorodność paraleli językowych w Starym Testamencie, retrowersja hebrajska nie jest jednoznaczna. Delitzsch proponuje: haras nediwim mikkiss'otam wajjarem szefalim, natomiast Bible Society: szallitim horid me'al kiss'otam, uszfalim sam lemarom. W obu propozycjach powtarzają się jedynie słowa kiss'ot (trony) i szefalim (poniżeni), jak również rdzeń czasownikowy ram (podnosić).

Werset Łk 1,52, a także następny stanowić będą egzemplifikację, czym są owe „wielkie rzeczy”, dokonywane przez Boga dla tych, którzy odczuwają przed Nim bojaźń. O ile paraleli na poziomie językowym nie znalazłem w Starym Testamencie, niemniej jednak myśl wyrażona w wersecie pojawia się dość często. W formie sześciu paraleli antytetycznych występuje w kantyku Anny:

Łuk mocarzy się tamie, a słabi przepasuja się moca, za chleb najmuja się syci, a głodni odpoczywaja, nieptodna rodzi siedmioro, a wielodzietna więdnie. To Pan daje śmierć $i \dot{z} y c i e$, wtraca do Szeolu i zeń wyprowadza. Pan uboży i wzbogaca, poniża i wywyższa.

$(1 \mathrm{Sm} 2,4-7)$ 
Zwłaszcza ostatnie słowa: maszpil 'af-meromem (poniża i wywyż$s z a)$, są paralelne z Łk 1,52. Kolejny werset kantyku Anny również może służyć jako skojarzenie reminiscencyjne

Z pylu podnosi biedaka,

$z$ barłogu dźwiga nędzarza,

by go wśród możnych posadzić,

by dać mu tron zaszczytny.

$(1 \mathrm{Sm} \mathrm{2,8)}$

O ile w kantyku Anny motyw tronu (kisse') występuje w kontekście nagrody dla poniżonego, to w pieśni Maryi w odniesieniu do poniżenia wyniosłych.

Antytezy wskazujące na Boga jako absolutnego władcę historii, mogącego odmieniać ludzkie losy celem zaprowadzenia sprawiedliwości, występują również w Księdze Hioba. Elifaz z Temanu, pragnąc przekonać Hioba o Bożej sprawiedliwości, mówi:

Wysoko podnosi zgnębionych, smutni się szczęściem wesela.

Udaremnia zamysty przebiegłych: dzieto ich rąk-nieskuteczne.

(Hi 5,11-12)

Również Hiob, odpowiadając Sofarowi z Naamy na jego zarzut dotyczący braku mądrości, powołuje się na to, co w tradycji sapiencjalnej stanowiło dowód wszechmocy i mądrości samego Boga:

Królów pozbawi ich władzy i sznurem skrępuje ich biodra.

Kapłanów pośle nierozważnych, powali największych mocarzy.

Głos uzdolnionym odbierze, rozsadku pozbawi i starców, pogarda okryje szlachetnych, bo pas odepnie mocarzom.

(Hi 12,18-19)

${ }^{8}$ Na temat skojarzeń reminiscencyjnych zob. Krzysztof Bardski, Krag biblijnych skojarzeń reminiscencyjnych J 8,31 w patrystycznej literaturze łacińskiej, „Scripturae Lumen" 4 (2012), s. 87-96. 
Werset Łk 1,52 odwołuje się do prawa odpłaty, uważanego w klasycznej tradycji mądrościowej za jedno z podstawowych narzędzi Boskiego zarządzania dziejami zarówno Izraela, jak i poszczególnych jednostek. Zostanie ono w sposób wyrazisty przedstawione w historii Hamana i Estery (Est). Wprawdzie i w Księdze Hioba, i w Księdze Koheleta autorzy podejmują polemikę z absolutną obowiązywalnością tej zasady, niemniej wciąż pozostaje aktualna. Wraz z rozwojem apokaliptyki zostanie poszerzona o wymiar eschatologiczny.

Kolejny werset w tłumaczeniu z greki brzmi: Zgłodniałych napetnit dobrami, a bogatych odestat z niczym ( $Ł \mathrm{k} 1,53$ ), natomiast $\mathrm{w}$ wersji hebrajskiej: Re'ewim milla'-tow wa'aszirim szillach reqam. Najbliższą paralelą starotestamentową, z której zresztą został zaczerpnięty materiał lingwistyczny do rekonstrukcji hebrajskiej, jest Ps 107,8-9:

Niech dzięki czynią Panu za Jego miłosierdzie, za Jego cuda dla synów ludzkich, bo nasycił tego, który jest łaknacy, i zgłodniałego napetnił dobrami.

Nawet całe wyrażanie kończące powyższy cytat: nefesz re'ewa milla'-tow (literalnie: duszę zgłodniała napełnił dobrami), Bible Society wykorzystało w swojej rekonstrukcji, zmieniając jedynie liczbę mnogą na pojedynczą: nefesz re'ewim milla'-tow, bardziej przekonująca wydaje się jednak wersja Delitzscha.

W kantyku Anny odpowiednikiem wersetu jest 1Sm 2,5a ( $z$ a chleb najmują się syci, a głodni odpoczywaja), który wyraża tę samą myśl. Chodzi mianowicie o przewijającą się na kartach Starego Testamentu ideę Boga jako „goela”, czyli obrońcy i wybawcy najuboższych, odtrąconych i wykluczonych. Można by powiedzieć o pewnym wymiarze archetypicznym „opcji na rzecz ubogich”, która ma czerpać wzór z samego Boga, a najpełniej została zilustrowana narracyjnie w biblijnej Księdze Rut.

Następnie czytamy: Postawił przed sobą Izraela swojego stugę, pamiętając łaskawość (Łk 1,54). A w wersji hebrajskiej: tamach beJisra'el 'awdo lizkor 'et rachamaw. Przykłady Bożego działania przytoczone we wcześniejszych wersetach stanowiły wprowadzenie do tezy kończącej poemat, zawartej w Łk 1,54-55. Podobnie jak Bóg 
odwracał koleje dziejów na korzyść tych, którzy doznali krzywdy, tak i teraz wstawia się za Izraelem.

Z powyższym tekstem paralelny jest Ps 98,3: wspomniał na swoja łaskawość i na wierność dla domu Izraela. Idea Bożej pamięci i wierności danym obietnicom stanowi swoisty fundament dla nadziei Izraela i poszczególnych jednostek w chwilach doświadczeń. Również w błagalnej modlitwie Anny, poprzedzającej poczęcie Samuela, słowa: będziesz pamiętał o mnie i nie zapomnisz o swojej służebnicy $(1 \mathrm{Sm} 1,11)$, odgrywają kluczową rolę.

Istotne znaczenie w Łk 1,54 pełni wyrażenie Israēl paidos autou, które wraz z większością tłumaczy przekładamy Izraela swojego sługę, choć teoretycznie mogłoby również znaczyć: Izraela swoje dziecko. Kontekst jednak sugeruje powołanie się na ideę Izraela jako sługi Pańskiego ('ewed JHWH), obecną w słynnych czterech poematach Deutero-Izajasza. Wprawdzie tradycja chrześcijańska - w oparciu o epizod chrztu dworzanina etiopskiego z Dz 8,32-38 - odczytuje je w kluczu chrystologicznym, niemniej jednak wydaje się, że pierwotny zamysł, dotyczący metaforycznego znaczenia postaci sługi Pańskiego, miał raczej na uwadze personifikację ludu Izraela ciemiężonego w niewoli babilońskiej.

Ostatni werset kantyku: Zgodnie z tym, co powiedział naszym ojcom Abrahamowi i jego potomstwu [nasieniu] na wieczność ( $Ł k 1,55)$, w wersji hebrajskiej mógłby brzmieć: Ka'aszer dibber 'el-'awotenu le’Awraham ulzar'o ad 'olam. Dostrzec tu można ewidentną aluzję do obietnicy danej Abrahamowi, zarówno na poziomie teologicznym, jak i lingwistycznym, ponieważ ostatnie słowa hebrajskiej rekonstrukcji powtarzają (oczywiście ze zmianą sufiksu osobowego) fragment z Rdz 13,15: Bowiem cała ziemię, która ty widzisz, tobie oddam i twojemu potomstwu [nasieniu] na wieczność.

Można w tym miejscu również przytoczyć Iz 41,8: A ty Izraelu, mój sługo, Jakubie, którego wybrałem dla siebie, potomstwo [nasienie] Abrahama, którego ukochałem. Tekst ten bowiem łączy w sobie w tej samej sekwencji motywy literackie występujące w Łk 1,54 (Izrael jako sługa Boży) oraz w Łk 1,55 (potomstwo/nasienie Abrahama). 
Szczególna wzmianka o Abrahamie, pojawiająca się w zakończeniu kantyku Magnificat, może sugerować związek typologiczny pomiędzy postacią niepłodnej Sary, w której łonie Bóg wypełnia daną Abrahamowi obietnicę licznego potomstwa, a postacią Maryi, dzięki której dokonuje się ostateczne wypełnienie tej obietnicy.

Podsumowując, można stwierdzić bardzo wyraźne osadzenie kantyku Magnificat w myśli i kontekście literackim Starego Testamentu. Dokonuje się to najpierw na poziomie językowym. Zauważamy liczne frazeologizmy i sekwencje wyrazowe, które zostały zaczerpnięte zwłaszcza z Księgi Psalmów, ale również z innych tekstów starotestamentowych.

Następnie dostrzegamy ważne idee teologiczne, które znajdują swój wyraz w poszczególnych wersetach kantyku, takie jak idea radości mającej źródło w Bogu, błogosławieństwa związanego ze szczęśliwością, świętości Bożego Imienia, bojaźni Pańskiej, sapiencjalnej zasady odpłaty i sprawiedliwości Bożej, Izraela jako sługi Bożego i w końcu pamięci Boga i Jego wierności danej obietnicy.

Specyficzny wymiar nadają poematowi aluzje sugerujące relację typologiczną pomiędzy Maryją a wybranymi postaciami kobiecymi ze Starego Testamentu, takimi jak Sara, Lea, Miriam, Anna, Rut i Estera.

\section{Summary}

\section{The Biblical Context of „The Magnificat”}

The author casts „The Magnificat” against the thought and wide literary context of the Old Testament. He points to the three levels creating the background to the Canticle of Mary. The first of these concerns language, where the author addresses the attempts to retrovert the text from Greek to Hebrew. The following level deals with the analogies to selected Old Testament phrases and verses, whereas the third addresses the references to important concepts and ideas extant in the Old Testament. 